\title{
ANALYSIS OF POSSIBILITIES TO IMPROVE ENVIRONMENTAL OPERATING PARAMETERS OF MODERN COMPRESSION - IGNITION ENGINES
}

\author{
Tomasz Osipowicz' , Karol Franciszek Abramek', Dalibor Barta², \\ Paweł Droździel' ${ }^{3}$, Maciej Lisowski ${ }^{1}$
}

1 West Pomeranian University of Technology Szczecin, al. Piastów 19, 70-310 Szczecin, Poland, e-mail: tosipowicz@zut.edu.pl,kabramek@zut.edu.pl,mlisowski@zut.edu.

2 University of Žilina, Faculty of mechanical engineering, Univerzitná 1, 01026 Žilina, Slovak Republic, e-mail: dalibor.barta@fstroj.uniza.sk.

3 Lublin University of Technology, Faculty of Mechanical Engineering, Institute of Transport, Internal Combustion Engines and Ecology, 36 Nadbystrzycka Street, 20-618 Lublin, Poland, e-mail: p.drozdziel@pollub.pl

Received: 2018.04.19

Accepted: 2018.05.16

Published: 2018.06.01

\begin{abstract}
The aim of this study was to analyse the possibilities of improving the ecological parameters of compression - ignition CI engines. During the analysis of exhaust gas, attention was mainly paid to the emission of nitrogen oxides and carbon black soot. A method was proposed to reduce the above chemical elements in CI - engine exhaust fumes by using the annular channels on the non-working part of the fuel injector needle and applying a platinum catalyst on them. The task of these annular channels is to mix and agitate the fuel before injection to the combustion chamber and to enlarge the contact surface area of catalyst. The task of catalytic coating is to initiate the reaction of dehydrogenation of paraffinic hydrocarbons to olefinic ones with a free hydrogen molecule. Hydrogen, owing to its properties, can shorten the period of delay of spontaneous ignition of combustible mixture in the engine combustion chamber, which affects the entire combustion process and improves the ecological parameters of a CI engine.
\end{abstract}

Keywords: fuel injector, compression-ignition engine, diesel fuel, dehydrogenation of hydrocarbons.

\section{INTRODUCTION}

Compression - ignition engines are being slowly withdrawn from modern motor cars due to the presence of harmful compounds in exhaust gas. The most toxic constituents of exhaust gas are carbon black soot, soaked up with hydrocarbons, nitrogen oxides, unburned hydrocarbons and carbon oxides. To reduce the concentration of toxins in exhaust fumes, newer and newer fuel injection systems, catalytic converters, diesel particulate filters and various fuel additives are used [2]. Research is also conducted in using catalysts in the engine combustion chamber and on fuel in- jection system elements [6]. Environmental standards and ecological fees as well as development of electric propulsion systems make use of motor cars equipped with $\mathrm{CI}$ engine as urban vehicles to be less and less cost effective. However, these engines are a primary source of propulsion in road, water and rail transport.

There is a possibility of reducing the emission of toxic substances in exhaust fumes to the atmosphere by using fuel spray nozzles with the channels in the form of annuli being cut on the non-working part of the fuel injector needle proposed by the authors. In addition, a catalytic coating is being applied on the annular channels 
which could have substantial influence by hydrogen powered [3]. The purpose of applied fuel spray nozzle design modifications is to improve the course of combustion process in CI - compression engines. The process of fuel-air mixture combustion consists of several stages. The first and the foremost one is the period of spontaneous ignition delay. It is the time between the appearance of first fuel drops in the combustion chamber and the occurrence of spontaneous ignition centres. It affects directly the second stage (kinetic combustion) because a shorter delay means less fuel in the cylinder and, as a result, the second stage takes place less rapidly. The solution in the form of annular channels proposed by the authors aims to atomise fuel particles shortly before injection to the combustion chamber in order to improve its mixing with air and to enlarge the contact surface area of catalyst on the non-working part of the fuel injector nozzle. The task of catalytic coating is to initiate the reaction of hydrocarbons dehydrogenation. Fuel for $\mathrm{CI}$ - compression engines is mainly composed of paraffin hydrocarbons $\left(\mathrm{C}_{\mathrm{n}} \mathrm{H}_{2 \mathrm{n}+2}\right)$. Due to the catalytic reaction, it is possible to dehydrogenate these hydrocarbons to the olefinic form $\left(\mathrm{C}_{\mathrm{n}} \mathrm{H}_{2 \mathrm{n}}\right)$ with hydrogen molecule separation. The properties of hydrogen, such as broad flammability limits, high diffusion coefficient in air, ability to spontaneous ignition and combustion rate, can shorten the period of ignition delay [11]. Essential meaning gains appear turbulent and cavitation phenomena by using channel rings [9]. The offered solution modification of fuel injector nozzle could be used in Common Rail system $\mathrm{CI}$ - engines [13]. The solution presented in the paper could have influence in LCA vehicle life cycle $[4,10]$, whereas don't influence it on diagnose technology technical conditions of fuel injector [14]. It acquires significance at present using varies sort of fuel to power engines and their influence on stability and reliability [8]. This solution does not have influence on working fuel injectors according to authors.

When analysing the relevant literature, the period of spontaneous ignition delay can be calculated according to J. B. Heywood from the following relationship [7]:

$$
\tau=\left(0.36+0.22 \cdot \mathrm{c}_{\mathrm{m}}\right) \cdot \exp \left[\mathrm{E}_{\mathrm{a}}\left(\frac{1}{\mathrm{RT}_{2}}-\frac{1}{17.19}\right) \cdot\left(\frac{21.2}{\mathrm{P}_{2}-12.4}\right)^{0.63}\right]
$$

$\mathrm{c}_{\mathrm{m}}-$ piston speed $[\mathrm{m} / \mathrm{s}]$

$\mathrm{E}_{\mathrm{a}}-$ activation energy [J]

$\mathrm{R}$ - universal gas constant $[\mathrm{J} /(\mathrm{mol} \cdot \mathrm{K})]$

$\mathrm{T}_{2}$-temperature in combustion chamber $[\mathrm{K}]$

$\mathrm{P}_{2}$ - pressure in combustion chamber [MPa]

Analysing the relationship that determines the period of spontaneous ignition delay, it is possible to state that it is conditioned by such factors as: pressure and temperature the combustion chamber, rotational frequency and engine piston-crank system kinematics, as well as activation energy value. Engine parameters, such as pressure, temperature and basic design components, could not be changed. There is a possibility to improve the ecological parameters of compression - ignition engines through shortening the spontaneous ignition delay by reducing the value of activation energy [1,2]. The solution proposed by the authors will affect the values being discussed and consequently will improve the ecological parameters of compression - ignition engines.

\section{STUDY OBJECTIVE AND SCHEME}

The research objective of this paper is to analyse the possibilities of improving the ecological operating parameters of $\mathrm{CI}$ engines by using the annular channels with a catalytic material on the non-working part of the fuel injector needle. The solution being proposed by the authors can be applied in any type of fuel injection system (mechanical injectors, unit injectors, and CR injectors) in passenger cars and goods vehicles, vessels, various machines, as well as in propulsion systems of locomotives being powered by CI engines.

The tests described below were prepared according to the following scheme:

- analysis of the effect of annular channels and catalysts on the physicochemical processes of fuel injection and combustion in a CI engine, 


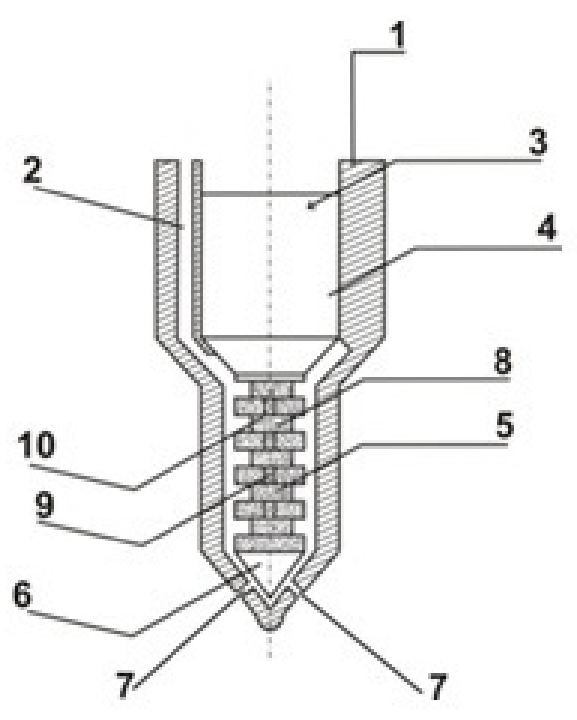

Fig. 1. Unmodified fuel spray nozzle:1 - fuel spray nozzle, 2 - fuel supply channel, 3 - spray nozzle needle, 4 - barrel and plunger assembly of the needle, 5 - non-working part of the needle, 6 - conical valve opening and closing the spray nozzle, 7 - holes supplying the fuel from the spray nozzle to the combustion chamber, 8 - catalytic material applied on the non-working part of the needle, 9 - annular channels on the non-working part of the needle, 10 - needle

space

- selection of the type of fuel injector,

- development of the object of physical research model,

- performance of laboratory tests,

- performance of engine tests.

\section{PRESENTATION OF TEST OBJECTS AND TEST BEDS}

The test objects are Common Rail fuel injectors manufactured by Bosch, serial number 0445 110083 . In the fuel injectors, fuel spray nozzles were modified (Figure 1) [12].

Fuel under high pressure gets from a fuel injector to a spray nozzle through the fuel sup-

a)

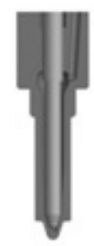

b)

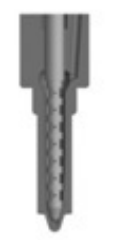

Fig. 2. Common Rail fuel injector nozzle: a) - standard, b) - modified ply channel (2) to the needle space (10). Next, it flows over the non-working part of the fuel injector needle and, as a result of fuel injector operation, is being injected into the combustion chamber of CI compression engine. The annular channels made on the not-working part of the fuel injector needle induce atomisation and agitation of fuel particles and enlarge the contact surface of catalytic coating. In addition, a catalytic coating in the form of platinum is applied on the non-working part of the fuel injector needle. The purpose of applying the catalytic coating is to activate the reaction of dehydrogenation of paraffinic hydrocarbons to olefinic ones with separation of free hydrogen molecule. The modified spray nozzles can be used in any type of fuel supply system of CI compression engine.

Figure 3 presents a CR fuel injector standard and modified spray nozzles [12].
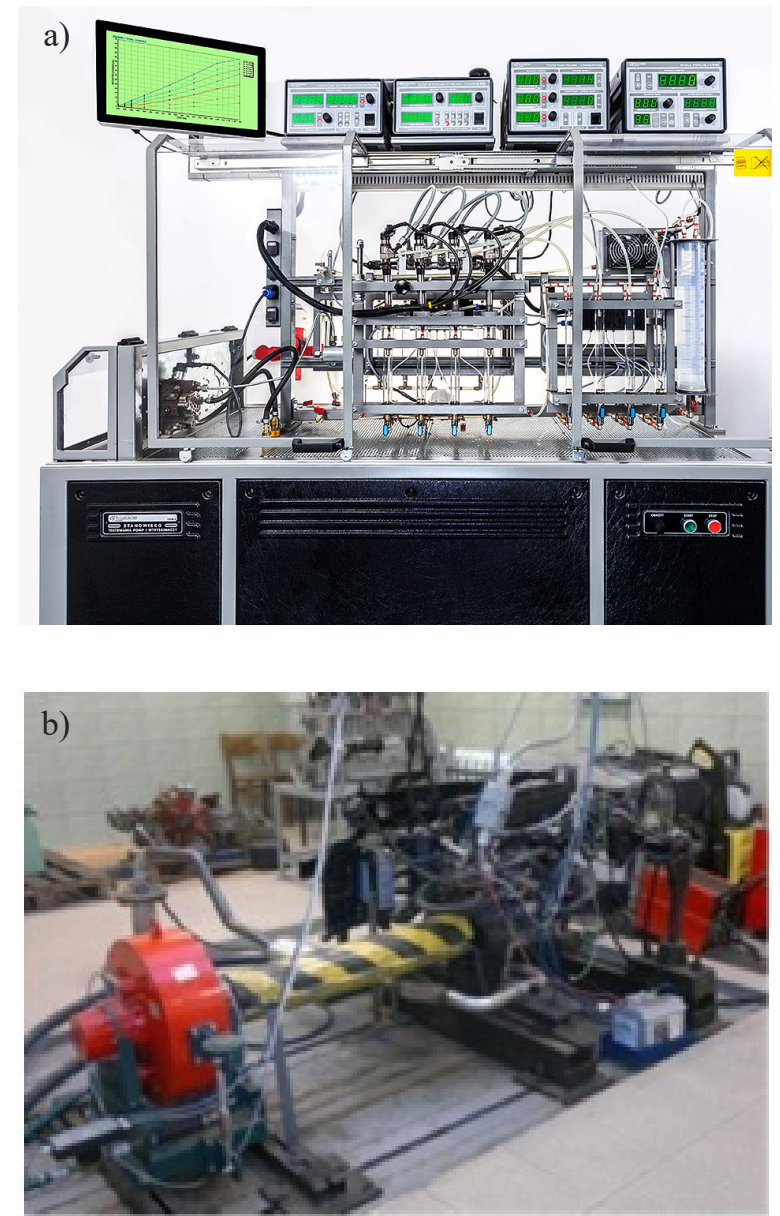

Fig. 3. a) Test bench STPiW-3 (Fuel Injection Pump and Fuel Injector Test Bench), b) Engine test bench Fiat 1,3 JTD MULTIJET 16V with dynamometer EMX 100/100 
Table 1. Results of injection and return dose testing for a factory-made fuel injector

\begin{tabular}{|c|c|c|c|c|c|}
\hline \multicolumn{7}{|c|}{ Fuel injector, serial number 0445110083, with a modified spray nozzle } \\
\hline \multirow{2}{*}{ Test number } & \multirow{2}{*}{ Test parameters } & \multicolumn{2}{|c|}{ Fuelinjectiondose } & \multicolumn{2}{c|}{ Fuel return dose } \\
\cline { 3 - 6 } & & Set value & Actualvalue & Set value & Actualvalue \\
\hline 1 & $145 \mathrm{MPa}, 60 \mathrm{~s}$ & 0 & 0 & $0.00-72.00$ & 34.1 \\
\hline 2 & $135 \mathrm{MPa}, 780 \mu \mathrm{s}$ & $34.71-49.69$ & 46.6 & $16.00-58.00$ & 32.3 \\
\hline 3 & $30 \mathrm{MPa}, 420 \mu \mathrm{s}$ & $0.31-3.89$ & 1.9 & $0.00-72.00$ & 7.1 \\
\hline 4 & $80 \mathrm{MPa}, 260 \mu \mathrm{s}$ & $0.31-4.09$ & 2.4 & $0.00-72.00$ & 9.0 \\
\hline
\end{tabular}

Table 2. Results of injection and return dose testing for a modified fuel injector

\begin{tabular}{|c|c|c|c|c|c|}
\hline \multicolumn{6}{|c|}{ Fuel injector, serial number $\mathbf{0 4 4 5 1 1 0 0 8 3 , ~ w i t h ~ a ~ f a c t o r y ~ - ~ m a d e ~ s p r a y ~ n o z z l e ~}$} \\
\hline \multirow{2}{*}{ Test number } & \multirow{2}{*}{ Test parameters } & \multicolumn{2}{|c|}{ Fuelinjectiondose } & \multicolumn{2}{c|}{ Fuel returndose } \\
\cline { 3 - 6 } & & Set value & Actualvalue & Set value & Actualvalue \\
\hline 1 & $145 \mathrm{MPa}, 60 \mathrm{~s}$ & 0 & 0 & $0.00-72.00$ & 21.32 \\
\hline 2 & $135 \mathrm{MPa}, 780 \mu \mathrm{s}$ & $34.71-49.69$ & 44.1 & $16.00-58.00$ & 27.53 \\
\hline 3 & $30 \mathrm{MPa}, 420 \mu \mathrm{s}$ & $0.31-3.89$ & 2.65 & $0.00-72.00$ & 6.45 \\
\hline 4 & $80 \mathrm{MPa}, 260 \mu \mathrm{s}$ & $0.31-4.09$ & 1.34 & $0.00-72.00$ & 7.14 \\
\hline
\end{tabular}

Laboratory tests were performed using a test bench for CR fuel injector testing - STPiW-3 (Figure 2). Engine tests were performed using the test bench Fiat 1,3 JTD MultiJet with dynamometer EMX 100/1000 (Figure 3).

\section{RESULTS OF LABORATORY AND ENGINE TESTS}

The first stage of researches was the analyse operation parameters CR fuel injectors on the STPiW 3 test bench. The aim was to check if the fuel injector with a modified spray nozzle works properly. Fuel injection and return doses were researched next to different adjustment of fuel injector. Two fuel injectors were subjected to testing - the first one with a factory-made spray nozzle, and the second one with a spray nozzle

\section{Injection dose}

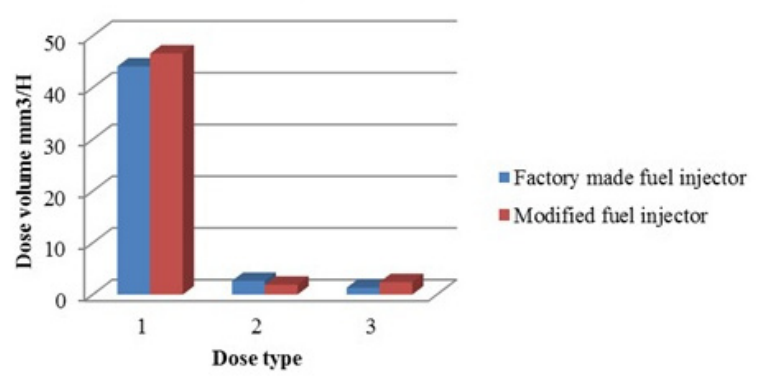

Fig. 4. Measurement results for fuel injection dose with annular channels and a catalytic coating being applied (Table 1, Table 2).

The measurement results are presented in graphical form (Figure 4, Figure 5).

In the next stage, bench tests were performed on Fiat 1,3 JTD with Common Rail fuel injection systems (Figure 6, Figure 7, Figure 8, Figure 9, Figure 10, Figure 11).

\section{ANALYSIS OF EXPERIMENT METHOD}

The objective of this study was to examine the possibilities of using the system of annular channels with platinum catalytic coating on the non-working part of the fuel injector needle in compression - ignition engines.

The process of combustion, otherwise known as heat release, is a complex, rapidly occurring

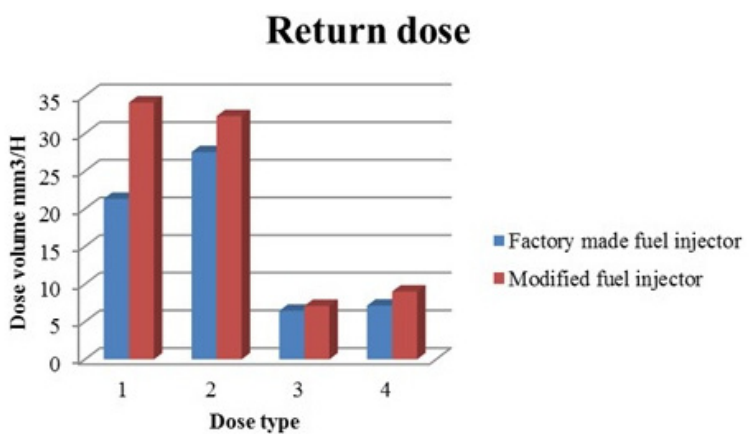

Fig. 5. Measurement results for fuel return dose 


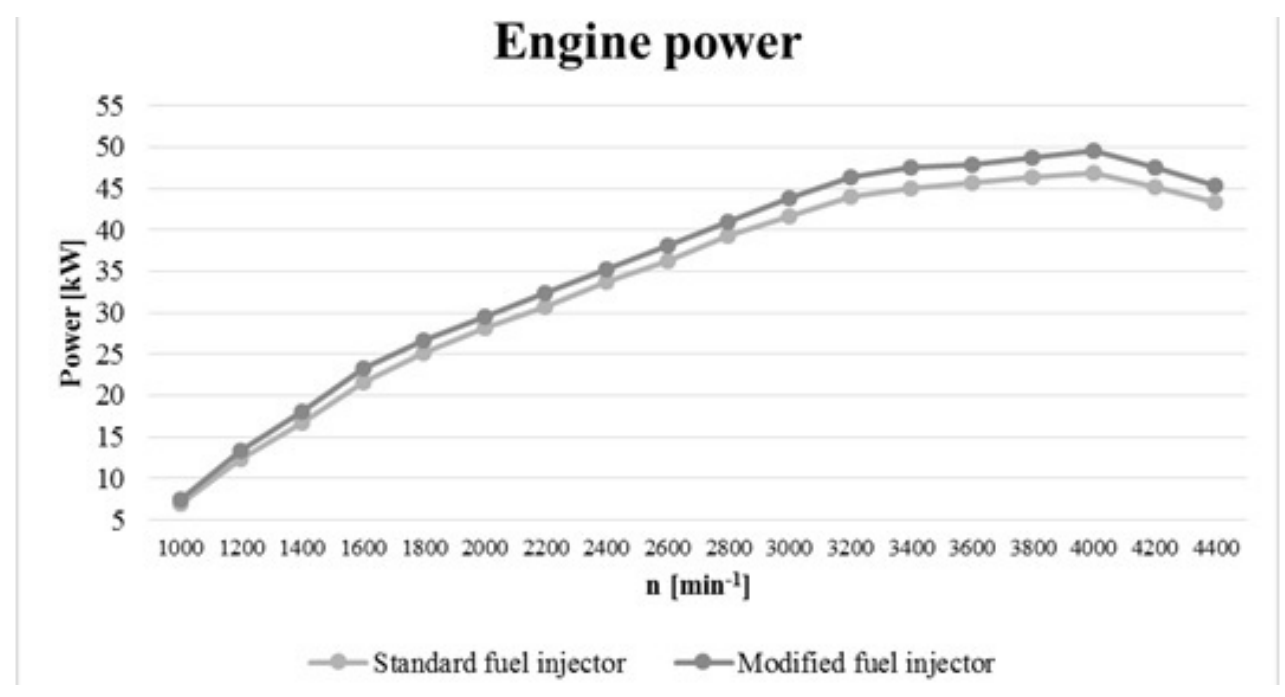

Fig. 6. The researches results on 1,3 JTD CR engine. Engine power

\section{Engine torque}

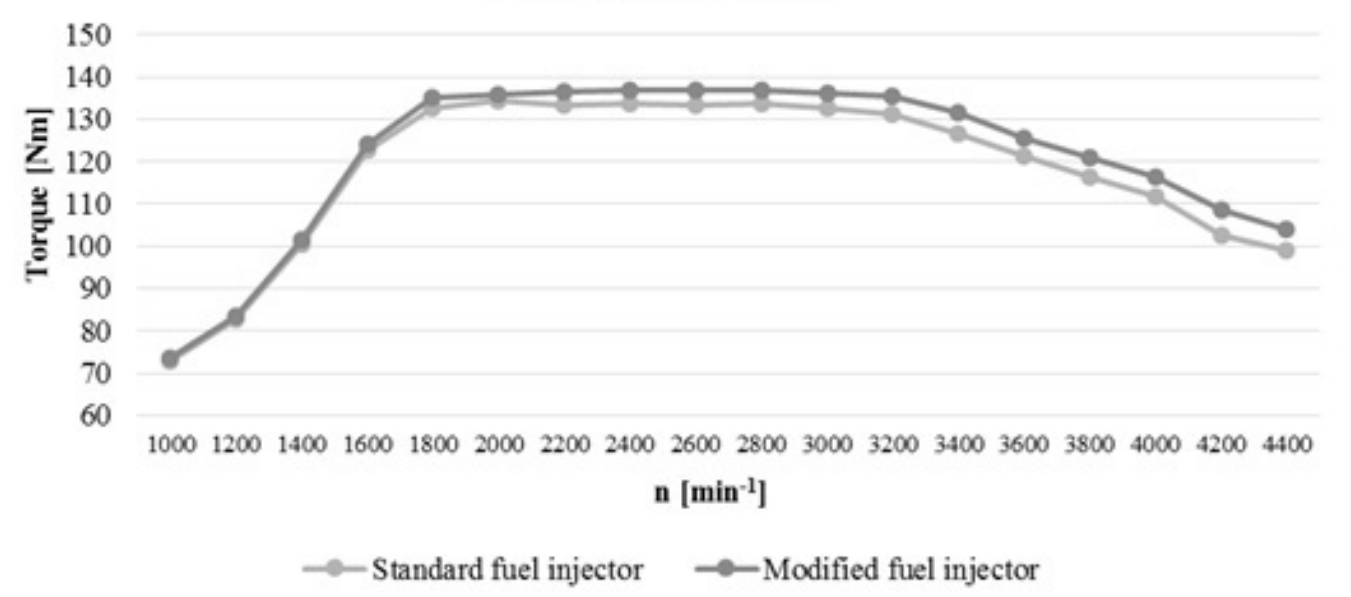

Fig. 7. The researches results on 1,3 JTD CR engine. Engine torque

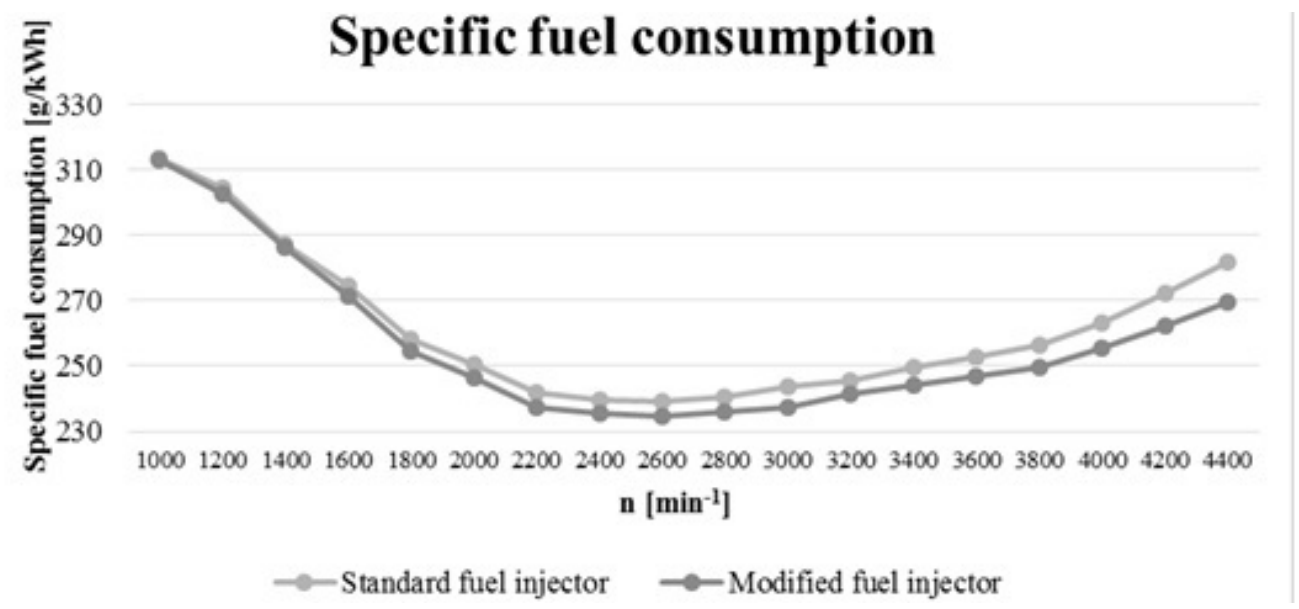

Fig. 8. The researches result 


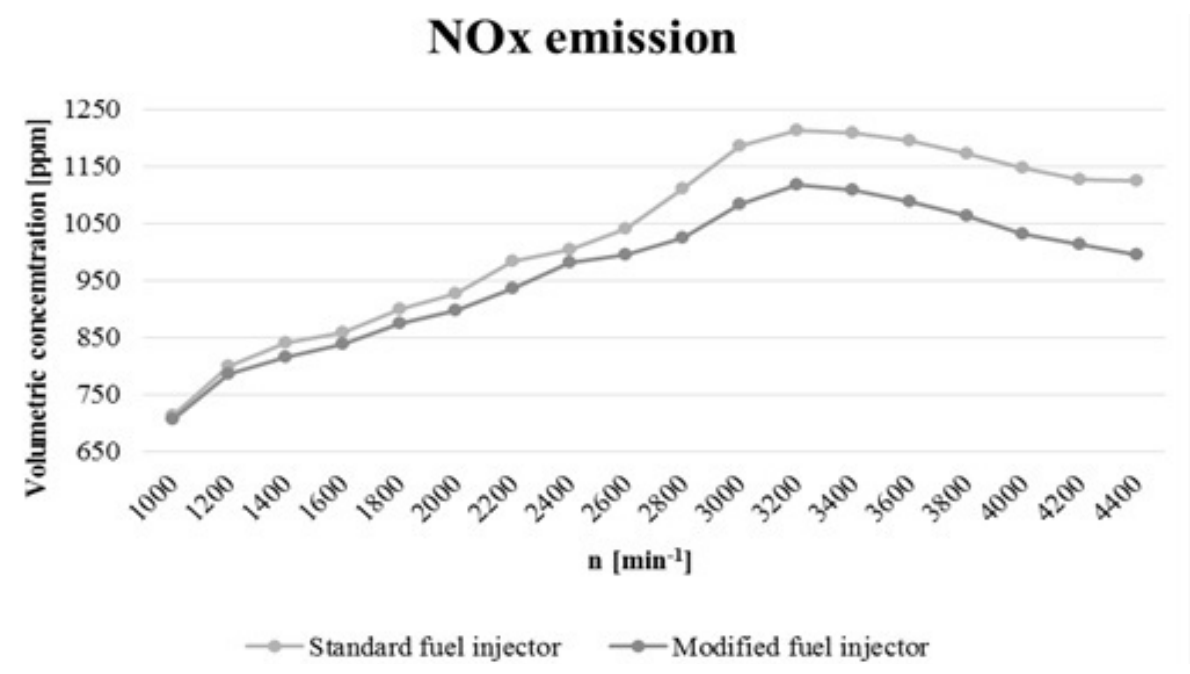

Fig. 9. The researches results on 1,3 JTD CR engine. Emission of nitrogen oxidise

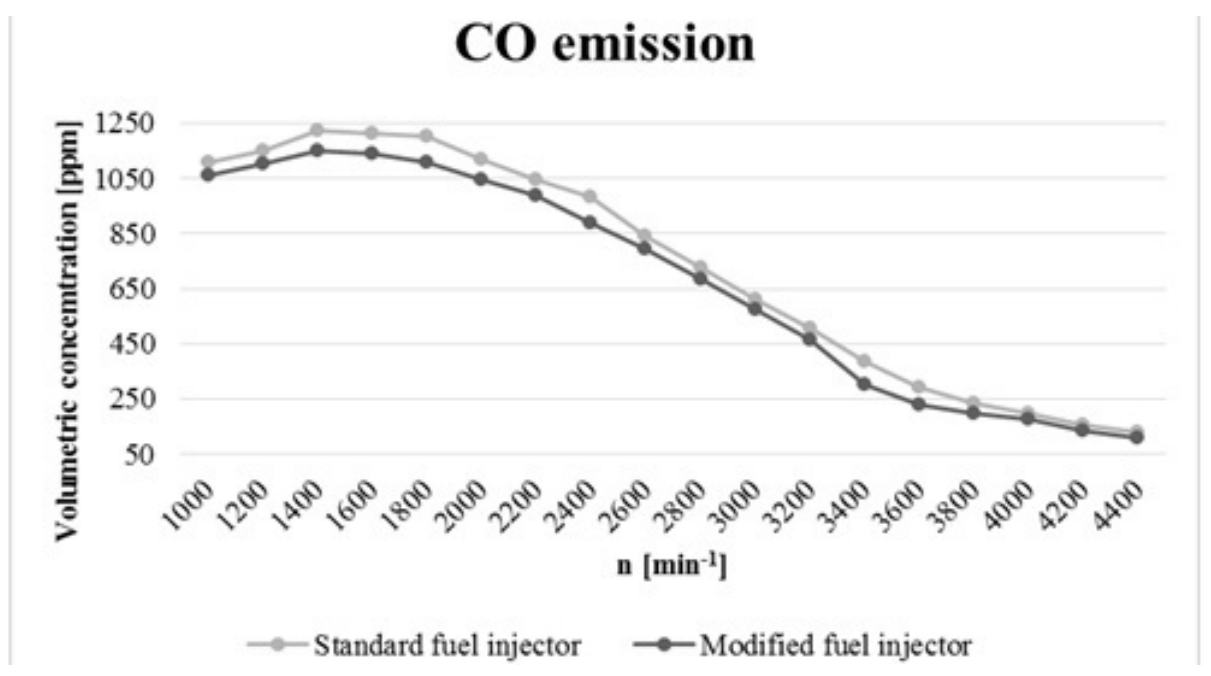

Fig. 10. The researches results on 1,3 JTD CR engine. Emission of carbon monoxide

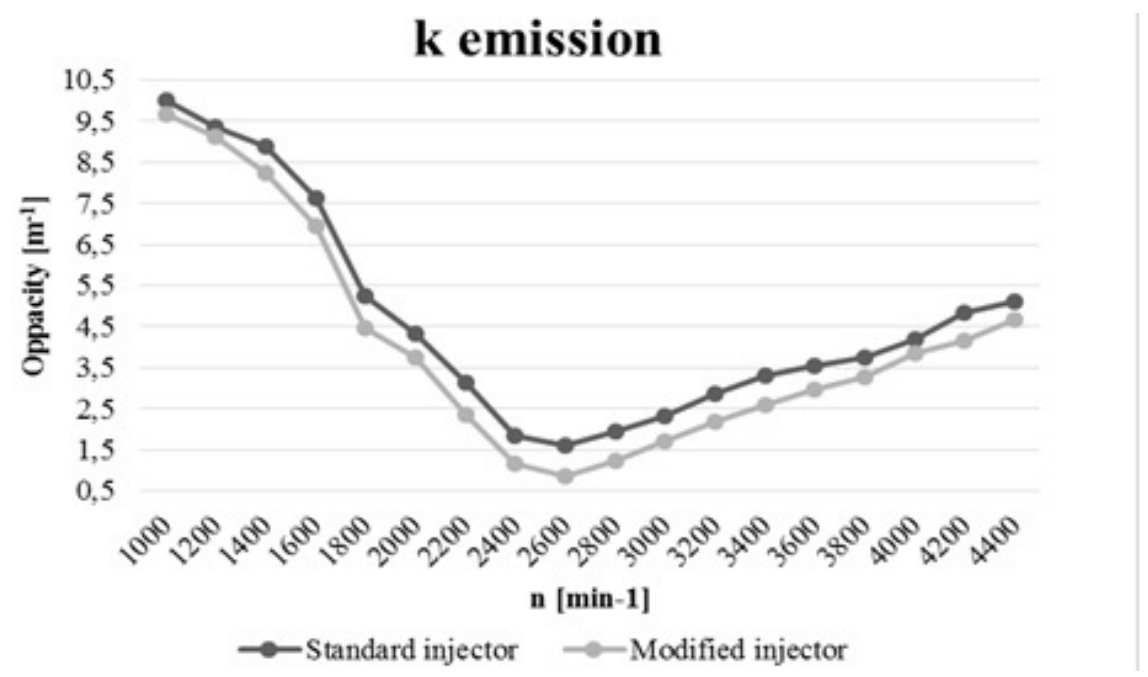

Fig. 11. The researches results on 1,3 JTD CR engine. Emission of particulate matter 
chemical reaction involving the combination of substances with oxygen, called oxidation. This reaction starts as the result of the collision of molecules, the energy of which is greater than the specific value of energy for each reaction and sufficient to break the existing intra-molecular bonds and replace them with new bonds inside the molecule. Such a limit value of energy is called the activation energy, while the molecules entering into the reaction are called chemically active molecules [11].

In the combustion process in compression - ignition engine, the following periods can be specified [6]:

- auto-ignition lag (delay) period, lasting from the beginning of fuel injection (usually it is determined based on the recording of fuel injector needle elevation time) until the start of combustion process, which is accompanied by a pressure curve bend (point of departure of the combustion curve from the compression curve).Factors affecting the auto-ignition delay period: ability to spontaneous combustion, fuel load temperature and pressure at the beginning of fuel injection, combustion chamber type, intensity of directed fuel load, fuel injection and atomisation characteristics, engine load changes, increase in engine crankshaft rotational speed.

- combustion period called the kinetic combustion phase corresponding on the diagram of ideal cycle to combustion at constant volume; it is characterised by a dynamic increase in heat release rate and lasts until the maximum value of this parameter has been achieved; pressure increase in this period is also very dynamic. Factor affecting the kinetic combustion phase: quantity and quality of fuel being supplied to the cylinder during the auto-ignition delay period and during kinetic combustion, rate of in-cylinder fuel load movement, combustion chamber type, engine load, engine crankshaft rotational speed.

- combustion period called the diffusion combustion phase corresponding on the diagram of ideal cycle to combustion at constant pressure, occurring near the TDC; the pressure curve bends due to a decrease in the rate of heat release $d Q / d \alpha$ and an increase in the combustion chamber volume. Factors affecting the diffusion combustion phase: quantity and quality of the atomisation of fuel being injected after starting the combustion pro- cess, rate of in-cylinder fuel load movement, engine boost, increase in engine crankshaft rotational speed.

- after-burning combustion period, lasting from the time of clear pressure drop being induced by already low rate of heat release and a clear increase in the combustion chamber volume. Factors affecting the after-burning combustion phase: turbulent pulsation of fuel load, quality of the atomisation of fuel being injected at the end of the injection process, fuel falling on cold surfaces of the cylinder space, engine boost.

\section{CONCLUSION}

The first stage of the study was to analyse the operation of Common Rail fuel injectors on a test bench. During the test, fuel injection doses and fuel return doses were examined. Examination on the test bench was a very important test because in the CR systems it is the fuel injector that is responsible for the volume of fuel injection doses. Modifications that were made on the non-working part of the fuel injector needle could affect them or overflow volumes. The overflow dose is a discharge of working fluid during the operation of fuel injector. Every CR fuel injector must have the overflow dose within the specific range. If it is too high, the system leaks and the regulator that controls the pressure will not be able to adjust its appropriate volume in the system. The overflow dose depends on many factors, among other on the state of barrel and plunger assemblies in the fuel injector. Modifications that were made on the not-working part of the fuel injector needle could affect the tightness of fuel spray nozzle, thus laboratory tests were very important. Laboratory tests showed that the use of annular channels did not affect the volume of fuel injection and fuel return doses in CR fuel injectors. It is very important because the research objective of this project is not to change the volume of fuel injection doses.

The analysis of laboratory and engine test results referring to the use of an innovative method of annular channel application on the spraying nozzle of modern compression ignition engine allows the following conclusions to be drawn: laboratory tests showed that application of annular channels does not affect the size of injection and return doses in the engine or the delay of fuel injection annular channels have an effect on the atomisation of injected fuel jet, which affects 
better mixing of fuel with air in the combustion chamber, owing to the modifications being made, an increase in engine power at medium and maximum rotational speeds, in torque at minimum and medium rotational speeds and a decrease in specific fuel consumption in the whole range of rotational speeds were observed. Also, an improvement in ecological parameters of the tested engine was noted. The largest decrease was observed in the emission of nitrogen oxides by average and maximum rotational engine speed.

When analysing the obtained results, it can be concluded that it is possible to improve the ecological parameters of CI - engines by using the annular channels with a platinum catalyst on the surface of the non-working part of the fuel injector needle.

Additional studies on the application of engine indication sensor should be conducted to illustrate the phenomena taking place in the combustion chamber when using annular channels. The next stage of examination will be to analyse the operation of engine with a modified fuel injector fuelled by biofuels and their mixtures with conventional fuel.

\section{REFERENCES}

1. Ambrozik A., Ambrozik T., Łagowski P. : Fuel impact of emissions of harmful components of the exhaust gas from the CI engines during cold start up. Eksploatacja i Niezawodnosc - Maintenance and Reliability, 17(1), 2015, 95-99.

2. Ambrozik A., Ambrozik T., Kurczyński D.: The influence of injection advance angle on fuel spray parameters and nitrogen oxide emissions for a self - ignition engine fed with Diesel oil and FAME. Pol. J. Environ. Stud, 23 (6), 2014, 1917-1923.

3. Balyts'kyi O. I., Kolesnikov V. O., Eliasz, J.: Study of the wear resistance of high - nitrogen steels under dry sliding friction. Materials Sciences, 48(5), 2013, 642-646.

4. Danilecki K., Mrozik M., Smurawski P.: Changes of the environmental profile of a popular passenger car over the last 30 years - Results of a simplified
LCA study. Journal of Cleaner Production, 141, 2017, 208-218.

5. Droździel P., Krzywonos L.: The estimation of the reliability of the first daily diesel engine start-up during its operation in the vehicle. Eksploatacja i Niezawodnosc - Maintenance and Reliability, 1. 2009, 4-10.

6. Heywood J.B.: Internal Combustion Engine Fundamentals, McGraw - Hill Inc. New York, United States of America, 1988, 498-551.

7. Janicka A., Walkowiak W.: The discursive attitude of emission vs. air-fuel mixture ignition delay in Diesel engine. Journal of Kones Powertrain and Transport, 13(4), 2006, 223-228,

8. Karczewski M., Szczęch L.: Influence of the F 34 unified battlefield fuel with bio components on useable parameters of the IC engines. Eksploatacja i Niezawodność - Maintenance and Reliability, 18(3) 2016, 358-366.

9. Molina S., Salvador F. J., Carreres M., Jaramillo D.: A computational investigation on the influence of the use of elliptical orifices on the inner nozzle flow and cavitation development in diesel injector nozzles. Energy Conversion And Management, 79, 2014, 114-127.

10. Mrozik M., Eliasz J., Trelak-Tymczyna A.: Material - energy model of motor vehicle life cycle. Strojarstvo, 55(2), 2013, 161-168.

11. Osipowicz T., Abramek K. F.: Catalytic treatment in Diesel engine injectors. Eksploatacja i Niezawodność - Maintenance and Reliability, 16(1), 2014, 22-28.

12. Osipowicz T.: Patent Application, No. 407545, 2015.

13. Payri R., Salvador F. J., Marti-Aldaravi, P., Martinez-Lopez J.: Using one-dimensional modeling to analyse the influence of the use of biodiesels on the dynamic behavior of solenoid - operated injectors in common rail systems: Detailed injection system model. Energy Conversion And Management, 54(1), 2012, 90-99.

14. Stoeck T., Osipowicz T.; Abramek K.F.:Methodology for the repair of Denso Common Rail solenoid injectors. Eksploatacja i Niezawodność - Maintenance and Reliability, 16(2), 2014, 270-275. 